Abstract

\title{
Breeding Low Emitting Ruminants: Predicting Methane from Microbes ${ }^{\dagger}$
}

\author{
Suzanne J. Rowe ${ }^{1, *}$, Melanie Hess ${ }^{1}$, Larissa Zetouni ${ }^{1}$, Sharon Hickey ${ }^{2}$, Rudiger Brauning ${ }^{1}$, \\ Hannah Henry ${ }^{1}$, Holly Flay ${ }^{3}$, Juliana Budel ${ }^{4}$, Brooke Bryson ${ }^{5}$, Peter Janssen ${ }^{6}$, Arjan Jonker ${ }^{6}$ \\ and John McEwan ${ }^{1}$ \\ 1 Invermay Agricultural Centre, AgResearch Ltd., Private Bag 50034, Mosgiel 9092, New Zealand; \\ melanie.hess@agresearch.co.nz (M.H.); larissa.zetouni@agresearch.co.nz (L.Z.); \\ rudiger.brauning@agresearch.co.nz (R.B.); hannah.henry@agresearch.co.nz (H.H.); \\ john.mcewan@agresearch.co.nz (J.M.) \\ 2 Ruakura Research Centre, AgResearch Ltd., Private Bag 3115, Hamilton 3214, New Zealand; \\ sharon.hickey@agresearch.co.nz \\ 3 DairyNZ, Private Bag 3221, Hamilton 3240, New Zealand; holly.flay@dairynz.co.nz \\ 4 Mestres em Ciência Animal, Universidade Federal do Pará in Brasil (UFPA), \\ Belem Do Pará 66095-903, Brazil; julianabudel@hotmail.com \\ 5 Woodlands Research Station, AgResearch Ltd., Woodlands RD1 9871, New Zealand; \\ brooke.bryson@agresearch.co.nz \\ 6 Grasslands Research Centre, AgResearch Ltd., Private Bag 11008, Palmerston North 4410, New Zealand; \\ peter.janssen@agresearch.co.nz (P.J.); arjan.jonker@agresearch.co.nz (A.J.) \\ * Correspondence: suzanne.rowe@agresearch.co.nz \\ † Presented at the Third International Tropical Agriculture Conference (TROPAG 2019), Brisbane, Australia, \\ 11-13 November 2019.
}

Published: 7 April 2020

\begin{abstract}
The greatest source of global anthropogenic methane $\left(\mathrm{CH}_{4}\right)$ emissions is from ruminant livestock. Multiple mitigation strategies in livestock are currently being explored. Of these breeding for lower $\mathrm{CH}_{4}$ emitting ruminants has the advantage of being permanent and cumulative and universally applicable to all classes of livestock. Here, we show that methane emissions can be predicted by the complex community of microbiota sampled from rumens enabling evaluation of systems and individuals. Furthermore, there is evidence that the microbial community is controlled not only be the feed substrate but also by the host itself and that selecting hosts that favour a microbial fermentation with lowered methane emissions changes the energy source to the animal, and in turn both rumen physiology and body composition. Current methods for obtaining microbial DNA and subsequent sequencing of an animal's microbiome, however, are too expensive to implement in commercial selection programs. A methodology that offers fast, low-cost, high throughput profiling of rumen microbiomes using Genotyping-by-sequencing (GBS) has been developed using an unbiased reference free approach to group microbiota. To date, this has been applied to over 4000 sheep samples and validated in cattle. Results show that microbial profiles are heritable and correlated with methane emissions and feed intake. This research is part of a flagship program funded by the global research alliance to disseminate global access to technologies that lower greenhouse gas emissions in ruminant livestock.
\end{abstract}

Keywords: methane; ruminant; microbiome; environment; breeding; genotyping-by-sequencing; green-house gas 
(C) 2020 by the authors. Licensee MDPI, Basel, Switzerland. This article is an open access article distributed under the terms and conditions of the Creative Commons Attribution (CC BY) license (http://creativecommons.org/licenses/by/4.0/). 